\title{
Debates sobre educação feminina no século XIX: Nísia Floresta e Maria Amália Vaz de Carvalho
}

\author{
Discussions about feminine education \\ in the 19th century: \\ Nísia Floresta and Maria Amália Vaz de Carvalho
} Emery Marques Gusmão

Até o século XVIII as famílias reservavam a escolarização e o letramento aos meninos, por serem tais atributos consideradas incompatíveis com a "identidade feminina", afirmada a partir do distanciamento em relação à alfabetização, leitura, produção de textos, profissionalização e participação na vida pública. A difusão, no século XIX, de escolas, jornais e literatura destinados ao público feminino parece representar um momento importante na redefinição do repertório cultural "apropriado" às mulheres. O movimento foi acompanhado com muita atenção por alguns segmentos conservadores da sociedade que, embora

Emery Marques Gusmão é professora do Departamento de Administração e Supervisão Escolar da Unesp campus de Marília, São Paulo, Brasil (emery@marilia.unesp.br).

Artigo recebido em 23 de janeiro e aprovado para publicação em 14 de agosto de 2012.

Est. Hist., Rio de Faneiro, vol. 25, no 50, p. 269-289, julho-dezembro de 2012. 
negassem a igualdade de direitos de homens e mulheres, defendiam a extensão a estas últimas do letramento, do domínio de línguas estrangeiras, de habilidades de conversação e desenvoltura social, a fim de que pudessem cumprir bem as funções de mãe e esposa nas sociedades urbanas. Esta lenta transformação parece ter sido mais ou menos simultânea em várias regiões, e alguns textos escritos por mulheres circularam entre os países.

Nísia Floresta, considerada nossa primeira feminista, desde 1830 publicou na imprensa comentários acerca das questões polêmicas de sua época (Duarte, 2005: 15), além de 15 títulos (em português, francês e italiano), em um momento em que eram raríssimas as mulheres brasileiras escritoras. São poemas, ensaios, romances e relatos de viagem, com destaque para a "tradução livre" de Direitos das mulheres e injustiça dos homens (1832), cuja versão original, lançada em 1792 na Inglaterra por Mary Wolstonecraft ( $A$ vindication of the rights of women), ao lado da Declaração dos direitos da mulher (1791), de Olympe de Gouges, representa um texto pioneiro no discurso que "ligava a emancipação das mulheres à implosão de todas as formas de hierarquia na sociedade" (Hunt, 2009: 172). Segundo Hunt, antes da publicação dessa obra o "conceito de direitos das mulheres quase não recebeu atenção", pois nem mesmo no contexto das revoluções Francesa ou Americana o "status das mulheres" foi objeto de "guerras de panfletos, competições públicas de ensaios, comissões do governo ou organizações de defesa”. As mulheres não constituíam uma minoria perseguida ou uma categoria política claramente distinguível; ninguém as forçava a mudanças de identidade; as leis limitavam seus direitos, e pensava-se que eram "moralmente senão intelectualmente dependentes dos pais ou maridos" (Hunt, 2009: 169). Assim,

tanto nos Estados Unidos, como na França, as declarações de direitos se referiam a 'homens', 'cidadãos', 'povo', e 'sociedade' sem cuidar das diferenças na posição política. [...] o abade Seyès tinha argumentado a favor de uma distinção entre os direitos naturais e civis do cidadão, de um lado, e os direitos políticos de outro. As mulheres, as crianças, os estrangeiros e aqueles que não pagavam tributos deviam ser somente cidadãos 'passivos' (Hunt, 2009: 148).

De Gouges insistia que a mulher nasce livre, permanece igual ao homem em direitos, e deve ter acesso às mesmas dignidades, cargos e empregos públicos; condenada como contrarrevolucionária imprudente e ser inatural (homem-mulher), acabou guilhotinada; Wolstonecraft não exigia todos os direitos políticos da mulher, mas foi vítima da difamação pública (Hunt, 2009: p. 172). A tradução da obra desta última por Nísia Floresta trouxe ao público bra- 
sileiro a denúncia da opressão feminina pelos homens - perspectiva que manteve em outros textos.

A primeira defensora dos direitos das mulheres no Brasil também redigiu apelos antiescravocratas e foi simpática à doutrina comtiana. Segundo Constância Duarte, a adesão de Nísia Floresta ao positivismo foi apenas parcial e esbarrou no feminismo, embora ambos defendessem a elevação do nível de instrução para mulheres:

Na doutrina comtiana, a superioridade feminina devia-se a uma suposta supremacia moral, afetiva e social da mulher e por ela ser capaz, no desempenho de seus papéis, de maiores provas de altruísmo. [...] Os deveres que estavam por detrás desta suposta superioridade são os previsíveis e encobriam apenas a real intenção de manter as mulheres num espaço único, longe de qualquer instância do poder [...] Ao anteciparmos que a adesão nisiana ao positivismo havia sido apenas parcial [...], lembrávamos, de um lado, os elogios feitos por ela à doutrina e ao autor; de outro, a independência de pensamento que conservou [...] (Duarte, 2002: 39-40).

Não se pode superestimar o alcance/repercussão dos textos de Nísia Floresta sobre a condição feminina; de qualquer modo, seus artigos publicados primeiramente no Diário do Rio de faneiro e depois n'O Liberal durante vários meses em 1852 e 1853, e reunidos no volume Opúsculo humanitário em 1853, "escandaliz[aram] as brasileiras e os brasileiros dos tempos imperiais" (Valadares, 1989: 1). O livro pode ser entendido como uma síntese de suas concepções relativas à educação feminina, e talvez por isso tenha permanecido de tal modo esquecido pela crítica que a segunda edição só apareceu 135 anos depois da primeira. De fato, a educação feminina representou uma inovação de grande impacto sobre a sociedade:

A ideia de manter as meninas no berço da ignorância foi a mesma que embalou o total desinteresse da alfabetização da população escrava. Ainda no período colonial, surgiram conhecidos ditos populares que revelavam essa cruel e preconceituosa visão: 'Mulher que sabe latim não tem marido nem bom fim' e 'Escravos que sabem ler acabam querendo mais do que comer' (Schumaher, 2003: 35).

A visão que "naturaliza" o desprezo, o preconceito e o esquecimento da mulher intelectual no século XIX pode ser problematizada por meio do con- 
fronto do Opúsculo humanitário de Nísia Floresta com a obra Mulheres e crianças, lançada em 1880 pela portuguesa Maria Amália Vaz de Carvalho em defesa da educação feminina. A autora portuguesa era consagrada pelo público e pela crítica, empenhados em afirmar tanto o valor de suas obras quanto suas qualidades morais - uma situação de exceção em face do tratamento discriminatório reservado à mulher de letras, segundo Maria de Fátima Outeirinho, que lembra a corrente denominação bas bleu aplicada à mulher autora, vista como "ridícula, sabichona, pretensiosa ou mesmo de moral duvidosa" (Outerinho, s/d: 299). Talvez se possa pensar que, nos Oitocentos, a recepção dos textos de autoria feminina, defensores da educação e do trabalho para mulheres, entre outros, dependia da maneira como o discurso fora elaborado e da inserção sociocultural da(s) autora (s).

Os termos "estabelecidos", establishment, established, "boa sociedade", com os quais Norbert Elias e John J. Scotson designaram grupos e indivíduos que ocupam posições de prestígio e poder nas comunidades com base nos princípios de antiguidade, tradição e autoridade - em contraposição aos outsiders, conjunto heterogêneo e difuso de indivíduos excluídos da "boa sociedade", muitas vezes estigmatizados, unidos por laços pouco intensos e alvos frequentes das fofocas depreciativas - nos levam à suposição de que a ascendência aristocrática de Maria Amália, o contato com os principais escritores e críticos literários portugueses do período (Camilo, Eça, Antero e Ramalho Ortigão, entre outros), que frequentaram o célebre salão literário mantido em sua casa durante anos, e o casamento com o também poeta Antonio Gonçalves Crespo asseguravam-lhe o reconhecimento social e o prestígio por ela prezados. Maria Amália escreveu em periódicos portugueses e brasileiros, foi a primeira mulher a ingressar na Academia de Ciências de Lisboa (1912), e conquistou a atenção e a consideração por meio da publicação de inúmeros ensaios, contos, poesias, biografias, crítica literária e análises acerca do papel da mulher e da educação na sociedade.

Já Nísia Floresta, "figura revolucionária da sociedade do século XIX" (Valadares, 1989: 4), parece mais ou menos marginal em relação aos círculos mais prestigiados da cultura letrada no Brasil (apesar do contato com importantes intelectuais europeus, como Auguste Comte, Alexandre Herculano e George Sand, entre outros), e o sucesso do Colégio Augusto, por ela fundado no Rio de Janeiro em 1838, permite supor justificativas comerciais para a campanha difamatória contra ela movida nos jornais. Pode-se supor igualmente que a defesa de ideais ousados na época (divórcio, voto feminino, anticlericalismo, abolicionismo, positivismo), e a ampla divulgação de seu posicionamento antiescravocrata (redigido em francês e italiano) entre os intelectuais europeus, que contribuiu "para preparar a intervenção da Junta Francesa de Emancipação, em 1866, junto 
ao Imperador, pedindo-lhe a abolição da escravatura no Brasil" (Duarte, 2002: 36), lhe tenha trazido inimizades. As biografias de Nísia Floresta mencionam ainda perseguições políticas contra sua família após a Revolução de 1824; o assassinato do pai, que a levou a buscar meios de sustentar a mãe e os três irmãos (Rosa, s/d); a anulação do primeiro casamento e a nova união com um estudante de Direito (evento que a indispôs com parte da família); mudanças de residência em várias regiões do Brasil (Pernambuco, Rio Grande do Sul e Rio de Janeiro) e Europa.

A inserção social distancia as autoras; no entanto, seus livros guardam pontos de proximidade: informam os leitores sobre os novos lugares reservados à mulher nas sociedades modernas, num momento em que a tradicional reclusão feminina era substituída por novas formas de sociabilidade que tanto permitiam a livre expressão das mulheres (como fez Nísia Floresta), quanto tornavam a postura feminina um "capital simbólico" capaz de contribuir para a ascensão ou decadência social da família (D'Incao, 1997: 229). As obras colocam a educação dos filhos, a supervisão da casa e a preservação da imagem pública da família sob a responsabilidade direta de uma mulher ativa, bem preparada, capaz de se apresentar de modo civilizado (à europeia); criticam o despreparo/distanciamento das mães para com a educação dos filhos, o apreço feminino pelas futilidades, os maus exemplos domésticos (homens dominadores, mulheres indolentes); defendem atividades/exercícios físicos e mentais para mulheres, e afirmam que ambos os sexos têm igual capacidade. Mas, enquanto Nísia Floresta denuncia a omissão e/ou má fé do governo, homens e instituições detentoras do poder para a educação desta nova mulher, Maria Amália Vaz de Carvalho recusa para si a expressão pública acerca das questões políticas de sua época (mesmo se relativas à educação feminina) e vislumbra mecanismos sutis, ardilosos (de eficácia duvidosa), para a afirmação do poder feminino no interior das famílias. Ou seja, na obra de Maria Amália Vaz de Carvalho, o distanciamento feminino em face das questões de interesse público tem como contrapartida o olhar atento sobre as relações na esfera privada - o olhar que se detém naquilo que atualmente chamamos "micropoderes" ou "política do cotidiano". A ousadia de Nísia Floresta deve-se a seu esforço de relacionar questões da esfera privada (como a educação das filhas) com a política institucional:

Quanto mais ignorante é um povo, tanto mais fácil é a um governo absoluto exercer sobre ele seu ilimitado poder. É partindo deste princípio [...] que a maior parte dos homens se opõe a que se facilite à mulher os meios de cultivar o seu espírito. Porém, esse é um erro que 
foi e será sempre funesto à prosperidade das nações, como à ventura doméstica do homem. (Floresta, [1853] 1989: 60).

Várias passagens da obra Mulheres e crianças (Carvalho, [1880] 1921) evidenciam que, na condição de autora, Maria Amália dirige-se exclusivamente às mulheres: "Leitora, quando tu vires passar triunfante, grosseiramente [...]" (p. 15); "[...] leitora querida, tu bem sabes [...]" (p. 35); "Queremos simplesmente falar ao bom senso das leitoras" (p. 30; "[...] receio por fim enfastiar as minhas leitoras" (p. 39); "Como sempre é à mulher que aqui me dirijo, é com a mulher que eu falo. O homem tem-se em muita conta para dar atenção à minha débil e desautorizada voz. A mulher entender-me-há [...]" (p. 62); "Mulheres, sede boas, cultivae o espírito [...]" (p. 127); "Leitora, quando o teu pequenino [...]" (p. 191); “[...] recomendo a todas as minhas leitoras [...]" (p. 206); "[...] capítulo que, talvez, [...] enfastiasse as leitoras [...]" (p. 214, grifos nossos).

Maria Amália indica às mulheres que posturas supostamente trariam harmonia ao mundo doméstico, e talvez se possa pensar que os "conselhos" mais ou menos explícitos da obra se distingam das sugestões de uma mãe à filha apenas pelo fato de que os argumentos não dispensam a contribuição da cultura letrada. Assim, chama a atenção na obra Mulheres e crianças - que, de fato, discute longamente o interior das residências e a relação entre os membros das famílias o lugar reservado ao livro: ao lado dos objetos de "verdadeiro luxo". A autora esforça-se para mapear os conflitos pessoais decorrentes da urbanização e da crise do patriarcado, em face da divisão das fortunas que tradicionalmente cabiam ao filho mais velho, encarregado também de acolher os irmãos, parentes pobres e as gerações de criados. No lugar de uma mulher dependente do pai, irmão ou marido, Maria Amália espera que a educação feminina seja capaz de fortalecer um novo tipo de mulher, aquela apta a "granjear dignamente o seu pão", "mesmo sozinha na vida" (p. 57):

[...] O homem preparando-se para casar também não dirá consigo: vou buscar um encargo. Dirá com muito mais propriedade: vou buscar um auxílio. [...] Provirá desta nova interpretação do casamento o haver menos mulheres solteiras. As que houver, porém, terão o seu lugar, o seu destino, a sua tarefa. Trabalharão (p. 58-59).

Em muitos momentos ficamos tentados a pensar que Maria Amália se preocupa com a independência da mulher, mas seu foco principal é a libertação do homem em relação ao encargo que representaria a mulher confinada no espa- 
ço doméstico ou nos salóes sociais, despreparada intelectualmente e incapaz de contribuir "adequadamente" na família e na sociedade burguesas. Para que a mulher não se torne um pesado fardo, defende o dote e, em alguns casos, a inserção no mercado de trabalho:

[...] medo de se sujeitar ao trabalho incansável e tenaz que há de dar-lhe a independência, a dignidade, a livre posse do seu destino. Além do medo, a impossibilidade absoluta. Se nada sabe, o que há ela de fazer? Podia dirigir a contabilidade de uma casa de comércio importante. As mulheres com seu instinto de ordem, mais desenvolvido do que os homens, são próprias para esse gênero de trabalho. Podia, sendo medianamente ilustrada, ser caixeira de um estabelecimento de modas, de uma loja de papel, de um mercador de fazendas, etc., etc.... Tudo isso está em harmonia com a delicadeza dos seus órgãos. Podia ensinar línguas, ensinar música, ensinar e explicar as ciências que houvesse aprendido, a história, a aritmética, a literatura, a geografia. Podia, tendo alguns fundos que houvesse herdado de seus pais, estabelecer qualquer pequena indústria [...] Mas, como não sabe fazer nada disso, como a sua educação a pôs e a conserva num estado de absoluta e desoladora humildade, não tem senão três caminhos a seguir. Ou casar mesmo que não tenha pelo seu noivo nenhum sentimento de respeito [...] Ou ficar a cargo dos parentes ricos que, por comiseração, a acolham [...] A terceira hipótese já todos a adivinharam $[\ldots]$ (p. 50, grifos nossos).

João Esteves (2001) destaca que, na passagem do século XIX para o $\mathrm{XX}$, as mulheres portuguesas enfrentavam uma elevada taxa de analfabetismo $-85,4 \%$ em $1890 ; 85 \%$ em $1900 ; 81,2 \%$ em 1911 -, o que restringia ainda mais as já escassas escolhas profissionais. Na primeira década do século XX, multiplicam-se escritos de autoria de mulheres nos periódicos, e as escritoras são as responsáveis pelas associações feministas portuguesas, e por tornar público o questionamento do estatuto legal da mulher. Segundo o mesmo autor, nos anos posteriores à década de 1910, a importância das escritoras decresce na mesma proporção em que as professoras se colocam à frente dos debates.

Maria Amália pertence a uma geração anterior às escritoras feministas e, como mulher do seu tempo, apresenta propostas que hoje nos parecem tímidas, decorrentes da inserção da mulher no campo da cultura letrada e científica. Maria de Fátima Outeirinho recupera sua posição em face da obra e da vida da contemporânea George Sand, "mulher das letras”, cuja obra era lida em vários paí- 
ses no século XIX e, assim como Maria Amália, caiu no esquecimento (o citado "esquecimento" não se aplica à farta correspondência de George Sand, particularmente aquela trocada com Flaubert).

A moral rigorosa de Maria Amália não impede a admiração pela literatura de George Sand (pseudônimo de Aurore Dupin, 1804-1876), a polêmica escritora francesa que adotou o modo de vida da boemia literária, participou do movimento romântico, aderiu aos ideais socialistas de Saint Simon, participou do movimento de 1848, tornou-se conhecida pela "tumultuosa vida sentimental" e por usar trajes masculinos, e transformou-se no "exemplo maior, à época, da mulher a circular na esfera pública transgredindo expectativas e códigos sociais da sociedade burguesa no século XIX" (Outerinho, s/d: 300). Embora a considerasse um "symbolo da revolta e da independência", "musa dos desesperos byronnianos" (apud Outerinho, s/d: 303), Maria Amália não condena sua visibilidade pública num momento de quase monopólio masculino sobre a escrita, e sim a ênfase da imprensa nos "erros da mulher mortal" (apud Outerinho, s/d: 302); em sua opinião, deveriam ser lembradas as "geniais qualidades da immortal escriptora", que evidenciam a "invasão da mulher nos domínios do homem" (apud Outerinho, s/d: 304). Sustenta, ainda, que a literatura de autoria feminina oferece o mais "humilhante desmentido acerca das suas theorias sobre a inferioridade do cérebro da mulher, sobre a sua impossibilidade de chegar a uma certa elevação esthetica que elle julgava ser apanagio de sua regia pessoa" (apud Outerinho, s/d: 304). Em um momento de revisão do que seriam práticas culturais femininas legítimas ou ilícitas, Maria Amália defende a leitura e a escrita para as mulheres (competências vistas como perigosas) sem, no entanto, dispensar os papéis tradicionais da família na sociedade. No seu entendimento, "a mulher de gênio pode ser, deve ser, melhor dona de casa, melhor mãe, melhor esposa, melhor amiga do que a mulher ignorante ou medíocre" (apud Outerinho, s/d: 304). É a partir deste olhar que ela redige os textos sobre educação feminina.

A obra Mulheres e crianças evidencia que, de fato, Maria Amália não concebe um modelo único de educação para homens e mulheres e para mulheres de diferentes grupos sociais (aristocracia, burguesia e populares). Por outro lado, os grupos sociais são entendidos como portadores de uma cultura peculiar, e são considerados fortemente abalados pela incipiente democratização e modernização da sociedade portuguesa. Neste contexto, caberia à mulher superar suas limitações pessoais e sociais - o que põe em destaque o sempre citado conservadorismo e a falta de sensibilidade em relação às reais dificuldades das mulheres e das classes desfavorecidas.

Pode-se observar sua percepção do impacto da "democracia" sobre a vida cotidiana, quando aborda a questão dos empregados domésticos: 
D'antes a família era fundada num princípio de muito menos justiça, mas numa base de muito mais solidez. Havia o chefe que acolhia [...] os irmãos, os parentes pobres, os filhos, os servos, que era uma tradição e também uma herança. Quando o chefe morria sucedia o filho ou o irmão mais velho, que herdava os irmãos, os tios, os parentes pobres, os servos, todos os haveres e também todos os encargos da numerosa comunidade. Os creados entravam no colo de sua mãe [...] e saiam no caixão para o cemitério, deixando na família nova geração de servos que eram seus filhos. [...] havia estabilidade [...] Não receiavam o dia de amanha $[. .].[\ldots]$ a sorte deles e dos seus estava [...] identificada com a sorte dos amos. [...] No regime moderno [...] As fortunas extremamente divididas já não consentem esse modo de viver opulento e patriarcal. [...] os financeiros modernos, estes que juntaram a fortuna [...] à custa de privações e de trabalho, são egoístas para todos [...] Na sua opinião, os creados são maquinas [...].[Os criados] Compreendem perfeitamente que são ridículos, eles (patrões) que andaram tanto tempo de tamancos, a varrer os armazéns [...] dando-se agora aqueles ares superiores e desdenhosos [...] percebendo o seu desastramento, os seus gestos grosseiros [...] o creado de hoje triunfa quando seus amos se rebaixam (p. 164-166).

Mulheres (mães e filhas) burguesas e aristocratas são duramente criticadas ao longo de toda a obra, por representarem as mulheres de salão: a altiva burguesa, "a quem o trabalho forçado já não absorve e a quem as distrações dum espírito culto são vedadas" (p. 14), envergonha-se "da pobreza honesta em que vivera durante largo tempo", deseja "esmagar as que a esmagaram noutra época", e induz as filhas a venderem a "mocidade e os seus carinhos por um titulo avariado ou pelos milhões d'um negreiro enriquecido" (p. 15); já a aristocrata moderna (p. 19) é cheia de "preconceitos" e "ideias estapafúrdias" (p. 17), fanática até na devoção em que a "ideia luminosa [...] pregada pelo Cristo se subverte em mentiras" (p. 18) e incapaz de acompanhar, consolar e compreender a família. A representante moderna da lendária fidalga tradicional fala com viveza e elegância ( $p$. 18), domina umas poucas línguas, conhece algo da cultura estrangeira (sobretudo francesa), tem o "cérebro recheado de insignificâncias bonitinhas", mas desconhece "milhões de cousas que precisa de saber para estar em harmonia com o seu tempo" (p. 19).

Retomando o texto em que aborda a questão dos criados domésticos, pode-se afirmar que, posta a falta de dignidade dos aristocratas e financistas, a autora convida o leitor a entrar nas "casas burguesas, que constituem hoje a maioria" (p. 167): 
Vive-se com pouco, há uma ou duas creadas [...] Podia-se viver decentemente [...] O pai é funcionário bem colocado, o rendimento [...] é suficiente para uma vida medíocre e laboriosa. [...] aspira a subir de posto, quer de mais a mais a carta de conselho [...] Tem de ir aos chás do seu amigo deputado, às soirées do barão de tal [...] tem de dar de jantar de vez em quando [...] Deve-se na tenda, [...] no carvoeiro, $[\ldots]$ na modista, $[\ldots]$ às creadas. Nas famílias pobres da burguesia, o casamento é julgado (pelas jovens filhas) a porta por onde se sai da miséria! (p. 167-169)

Tem-se a impressão de que a "mulher de salão", vaidosa e pretensamente sofisticada, distanciou-se dos "instintos" de mãe e mulher que a humilde plebeia preserva. Maria Amália parte do pressuposto de que haveria pelo menos dois tipos de mulher em sua sociedade: a "mulher de sala" (p. 17) e aquela que as "vaidades sociais ainda não corromperam". A segunda seria laboriosa, ignorante, ingênua, porém profunda, e capaz de preservar a "rude sensatez plebeia de sua raça" (p. 12):

Entendemos pois que os esforços de todos os educadores, de todos os que se preocupam com o futuro da sociedade devem convergir para anular a mulher dos salões e para crear e fortalecer a mulher de família (p. 24, grifos nossos).

A "mulher de família", capaz de compreender e ajudar o marido e os filhos, precisaria ser educada por meio de uma instrução que não apagasse a "sensatez". Embora Maria Amália publicasse textos regularmente, conhecesse as novidades literárias da época, e sua casa tivesse abrigado o primeiro salão literário de Lisboa, sua obra comunicaria os conhecimentos acumulados pelo primeiro grupo de mulheres (rudes plebeias):

Hoje [...] a corrente das ideias democráticas, purificou a atmosfera viciada [...]. Tudo se transfigurou [...] o pensamento reconquistou a sua independência perdida, e uma voz firme e poderosa bradou bem alto: - Não se trata de continuar no caminho que íamos trilhando [...]. Ouvir esta voz é renunciar aos erros do passado, e cumpre que nós mulheres renunciemos a eles para não caminharmos por uma estrada oposta àquela por onde vão subindo fortes, iluminados, convencidos, os nossos pais, os nossos esposos, os nossos irmãos. Nãoé uma pena 
obscura como é a minha que pertence dar leis absolutas sobre um sistema de educação diverso do que hoje está geralmente adaptado. Limitar-me-ei rapidamente e apenas animada com a força da consciência, consultado o bom senso que é apanágio dos mais humildes, e a observação que pode ser partilha dos mais pobres, a indicar alguns obstáculos que nos separam moralmente daqueles de quem somos companheiras e de quem devemos ser auxílio e complemento" (p. 23-24, grifos nossos).

Na condição de mulher, ela ouve a mesma voz a que os homens deram ouvidos (pronunciada em meio às ideias democráticas) e, diante da iminente transformação da sociedade e dos homens, registra sua percepção dos fatos, falhas e necessidades dos sujeitos; assim, não discute doutrinas políticas, mas o comportamento masculino e feminino de sua época; e apresenta propostas que os guiariam na "direção que conduz à verdade" (a moderna sociedade democrática). Em oposição às mulheres pedantes (burguesas ou aristocratas), sonha com o dia em que "a mulher instruída deixasse de ser uma exceção admirável" (p. 45), entendendo a educação como conhecimento que permite chegar a noções práticas e à "perfeição moral” (p. 47):

hoje há muito mais esmero [...] na instrução que as classes abastadas dão às suas filhas. Pouco mais precisam de aprender; o que lhes falta é a ligação lógica entre as várias coisas que aprendem, é uma concepção mais larga das mesmas ciências que adquirem (p. 45-46).

A instrução seria aliada na luta contra a "preguiça mental" e o tédio "esse inimigo poderoso da mulher" (p. 46). Para Maria Amália, os "novos tempos" demandariam a ação firme e consequente das mulheres, que precisariam de uma cultura eminentemente prática e aberta/sensível à contribuição da cultura dos demais segmentos. Deste modo, a mulher jovem ou madura, rica ou empobrecida, burguesa, aristocrática ou plebeia precisaria investir na preparação intelectual, trabalhar e superar as limitações pessoais e/ou sociais - esta seria uma exigência da época. Na mesma medida em que a obra critica os excessos da vida em sociedade e nos salóes, insiste no trabalho feminino "como condição indispensável à própria dignidade" (p. 25). Voltados para as mulheres, o trabalho e a leitura adquirem um novo significado: a educação feminina aberta aos conhecimentos científicos e literários deveria preparar para a vida social sem, no entanto, anular a "sensatez" mantida pelas rudes plebeias: 
é laboriosa e tem a rude sensatez plebeia de sua raça. Tem o amor dos filhos, um amor animal, um amor físico, mais instinto que religião. Não raciocina, mas sente com uma energia poderosa. É d'uma ignorância absoluta, ingênua, profunda, quase sublime na sua cegueira. Imagina-se porém investida d'um dever supremo a que todos se subordinam: o de proporcionar por todos os meios ao seu alcance o bem estar material do marido e da família. Não tem conversação, não tem espírito, não tem aquela doçura benévola que é para o coração dos homens o que o algodão em rama é para o ninho das aves. Quando aconselha, irrita; quando quer guiar, contraria, quando tenta convencer despersuade. É porém ativa, asseada, robusta, fiel [...] (p. 12)

Pode-se pensar que tal mulher laboriosa preserva um modo de ser e sentir que a autora considera tipicamente feminino e, por estes motivos (trabalho e modo de sentir feminino/materno), não precisa lutar contra o tédio. Do ponto de vista de Maria Amália, seus escritos poderiam ser entendidos como femininos (e não feministas), pois representariam o esforço de preservar/transmitir um saber intuitivo formulado a partir de diferentes matrizes, mas derivado da condição da autora mulher, filha e mãe. Mulheres e crianças é dedicado à mãe da autora e, na dedicatória da obra, ela afirma que escreveu "inspirada pelos seus conselhos e pelo seu santo e nunca desmentido exemplo". Este gênero literário que Maria Amália considera "feminino" seria uma necessidade da época, em face da dificuldade das mães aristocratas e burguesas compreenderem o instável mundo moderno que desmanchou no ar o que parecia sólido, fragmentou fortunas, tornou difícil o sustento dos agregados e dependentes e, desse modo, impeliu todos (homens e mulheres de diferentes inserções sociais) ao trabalho e ao preparo intelectual. Em uma linguagem abertamente coloquial, o texto cheio de adjetivos e metáforas adequados à leitura em voz alta, nas reuniões sociais (tão comuns à época), e no interior das casas, tornava pública uma discussão da esfera privada: a felicidade da mulher. A autora acredita que esta discussão não interessaria aos homens:

Como sempre é a mulher que aqui me dirijo, é com a mulher que eu falo. O homem tem-se em muita conta para dar atenção à minha débil e desautorizada voz. A mulher entender-me-há porque é em vista da sua felicidade, da felicidade dos seus filhos, da solidez e do aconchego do seu ninho que eu lhe estou aqui falando (p. 62, grifos nossos).

Retomando mais uma vez o texto que aborda a relação das mulheres com as criadas domésticas, deve-se destacar que ele propõe a educação das futuras cri- 
adas em instituições de caridade particulares e estatais, visto que elas não aprenderiam o serviço doméstico (e o sentimento feminino/maternal?) em família e ou com patroas. Fica-se tentado a pensar que tais meninas precisariam aprender as lides domésticas no asilo pelo mesmo motivo que as mulheres precisariam da literatura feminina: nas sociedades modernas, a escola e a palavra escrita preparam; nas sociedades tradicionais, os conhecimentos eram transmitidos oralmente, de geração em geração, e não se tornavam ultrapassados. As transformações sociais preocupam a autora e, com maior ou menor intensidade (dependendo do contexto), colocam em cena um novo sujeito histórico, a mulher socialmente livre, exercendo seus direitos. Segundo Maugue (s/d: 582-583), o sucesso da expressão "Nova Eva" (que passa de texto em texto na Europa, no século XIX) evidencia o quanto chamou a atenção este inusitado personagem.

Diferentemente de Maria Amália, Nísia Floresta atribui à má vontade e ao egoísmo masculinos as causas do despreparo e da dependência da mulher. De maneira simplificada, pode-se dividir o Opúsculo humanitário em duas partes: a primeira faz considerações de ordem histórica, a fim de demonstrar que, desde as primeiras civilizações (na Ásia), "a mulher foi sempre considerada como um instrumento do prazer material do homem, ou como sua mais submissa escrava" ([1853] 1989:2); a outra aborda a educação feminina, tomando como principal referência a contribuição das diretoras dos colégios, função que exerceu durante longos anos. A voz feminista de Nísia acusa os homens, detém-se pouco no aconselhamento às mulheres, mas denota o esforço (frequente entre as escritoras do período) de compreender/legitimar sua condição de intelectual - tradicionalmente um lugar masculino. Em meio a confusões entre o masculino e o humano (Maugue s/d: 598), o desejo de reconhecimento social e a necessidade de encontrar meios de subsistência, os escritos femininos do período evidenciam que, em alguns casos, as novas Evas sentem-se socialmente excluídas. Mme de Staël, ${ }^{1}$ por exemplo, afirma a "existência singular" da escritora:

Se existisse uma mulher seduzida pela celebridade de espírito e que quisesse tentar obtê-la, como seria fácil dissuadi-la se houvesse ainda tempo! Mostar-se-lhe-ia a que destino terrível ela estaria prestes a condenar-se! [...] a opinião pública parece libertar os homens de todos os deveres para com uma mulher à qual seria reconhecido um espírito superior: pode ser-se ingrato, pérfido, mau para com ela sem que a opinião pública se encarregue de a vingar. Não é ela uma mulher extraordinária? [...] ela passeia sua existência singular, como os Párias da Índia, entre todas as classes a que não pode pertencer, todas as classes que a consideram como que devendo existir por si só: objeto da curiosi- 
dade, talvez da inveja, e de fato apenas merecedora de piedade (Staël, s/d: 609).

Para Maria Amália, a mulher culta estaria acima das demais e em condições de colocar-se ao lado do homem - a quem caberia do poder decisório. Assim, ela escreve às mulheres, "sobre a sua felicidade", e fornece orientações no sentido de fazer com que ajudem o companheiro (trabalhando, estudando, cuidando dos filhos etc.), e não se observa nos seus escritos o sentimento de exclusão social. Já Nísia associa a educação feminina ao regime político dos povos e, no seu entendimento, os colégios para moças seriam necessários em função do despreparo das mães para assumir o papel de preceptoras das filhas:

Uma mãe bem educada e suficientemente instruída para dirigir a educação de sua filha obterá sempre maiores vantagens [...] que qualquer diretora [...]. Para provar esta asserção, bastaria a experiência de duas meninas, de idênticos recursos intelectuais, submetidas uma aos cuidados de sua mãe, mulher de bons costumes [...] dando-se a possibilidade de conservá-la sempre sob suas vistas, outra sob a direção de uma preceptora (supomos também com iguais habilitações), de comum com grande número de companheiras [...]. Aos 18 anos, estas duas jovens poderão ser perfeitamente instruídas, mas não igualmente educadas [...]. A primeira será a esquisita delicada flor da estufa, desabrochando as lindas pétalas de uma coroa não tocada por impuros insetos, esparzindo o precioso aroma da inocência e da candura, a segunda a flor dos jardins, exposta aos contatos de malignos insetos e às variações súbitas da atmosfera, que lhes tiram por vezes o aroma, quando ela conserva ainda o brilhantismo de suas cores (Floresta, [1853] 1989: 92).

Nísia enumera os "vícios" da família brasileira, tais como o convívio com escravos, a falta de respeito à inocência da criança, a má conduta dos pais etc., e afirma que governo e pais brasileiros não reconhecem os danos das suas práticas educativas, nem se esforçam por bani-las (p. 109):

As lições e os esforços de uma ou outra pessoa, desta ou daquela família, nada podem contra [...] uma nação inteira. Um ou outro pai conseguirá educar bem seus filhos, mas, não estando esta educação no espírito do seu país, eles permanecerão estrangeiros no meio de nossa própria sociedade [...] (p. 108). 
Se Mme de Staël afirma a "existência singular" da escritora talentosa, Opúsculo humanitário considera os pais cultos uma exceção social, e talvez se possa pensar que é a eles que se dirigem os artigos publicados em jornais e reunidos em livro em 1853. Pode-se indagar: o debate visava influenciar esses leitores no sentido de afirmar a relevância/eficácia do Colégio Augusto, para meninas, fundado por Nísia no Rio de Janeiro e alvo de críticas anônimas - que incluíam a vida particular da própria Nísia, sua diretora - publicadas no fornal do Comércio em 1846? Fundado em 1838, o Colégio Augusto foi um dos primeiros colégios brasileiros que tiveram em seu comando alguém de nacionalidade brasileira, e tornou-se um dos mais conceituados da Corte. O sucesso e as inovações pedagógicas, que previam exercícios físicos e "matérias nunca antes oferecidas às moças" (Schumaher, 2003: 36), parecem justificar a polêmica. Observam-se, nos textos, a defesa da escola privada nacional, críticas à moralidade e à ação catequizadora do clero brasileiro, apontadas como responsáveis pelo "mau sistema de nossa educação doméstica" (p. 139), e a afirmação da necessidade de controle/inspeção das instituições de ensino por parte do Estado (particularmente um exame, elaborado pelo governo, para avaliar indivíduos que pretendessem exercer a função de diretores de colégios). O clero, os estrangeiros e o Estado brasileiro (responsáveis pela manutenção das poucas escolas femininas existentes no período) são criticados, e, deste modo, pode-se supor que os artigos de Nísia (de maneira intencional ou não) inserem-se em um debate que ameaçava a imagem pública do Colégio Augusto.

Em todos os pontos do Brasil, qualquer homem ou mulher que saiba ler, embora não seja o português classicamente belo de A. Herculano, e tem meios de montar uma casa de educação, julga-se para logo habilitado a arrogar o título de diretor de colégio, caricaturando o que na Europa ilustrada assim se denomina. Nenhum exame em regra se exige desses educadores [...]: eles ensinam pelos compêndios que querem, instituem doutrinas à sua guisa. $O$ pedante goza das mesmas garantias, e quase sempre de maiores vantagens, que as inteligências superiores. Seria difícil explicar vantajosamente a negligência com que um governo ilustrado deixa praticar assim abusos [...](p. 81).

Os textos publicados em jornais justificam a educação feminina a partir de considerações de ordem política - um posicionamento muito diferente daquele adotado por Maria Amália em Mulheres e crianças:

É a natureza do governo de cada sociedade [...] que estabelece a natureza da educação, que lhe fornece força ou fraqueza, ví- 
cios ou virtudes. Este princípio é incontestável, mas, se na insuficiência de enérgicas medidas do governo para a reforma de nossa educação, apelamos para os pais de família, é porque estamos convencidos de que, em um país onde a escravidão é permitida, deles dependem principalmente os meios de subtraírem seus filhos a grande parte dos inconvenientes que os prejudicam (p. 109, grifos nossos).

Os principais interlocutores de Nísia Floresta parecem ser esses pais/mães empenhados em vencer um meio hostil para formar mulheres que, assim como seus pais, serão exceções na sociedade brasileira:

Muitas de nossas brasileiras, apesar da atmosfera de subversivos princípios em que respiram, são, todavia, o modelo do sexo e a honra da humanidade. Filhas, elas respeitam seus pais [...]. Esposas, seu coração se compenetra religiosamente de seus deveres [...]. Mães dirigem com perseverante zelo a educação dos seus filhos [...]. A vida é para tais naturezas uma luta constante, de que saem sempre vitoriosas mas não felizes, porque não podem harmonizar seus nobres sentimentos com a degeneração de seu semelhante [...] (p. 104).

Na opinião de Nísia, no Brasil, as educadoras não ousam contrariar opiniões e gostos dos pais (p. 111), com receio de verem "suas aulas sem auditório" (p. 111), e por isso o magistério torna-se "objeto de especulação":

[...] o que se chama por via de regra no Brasil dar uma boa educação a uma menina? Mandá-la aprender a dançar [...] pelo gosto de a fazer brilhar nos salões; ler e escrever o português, que, apesar de ser o nosso idioma, não se tem grande empenho de conhecer cabalmente; falar um pouco o francês, o inglês, sem o menor conhecimento de sua literatura; cantar, tocar piano, muita vez sem gosto, sem estilo, e mesmo sem compreender devidamente a música; simples noções de desenho, geografia e história, cujo estudo abandona com os livros ao sair do colégio; alguns trabalhos de tapeçaria, bordados, crochê, etc., que possam figurar pelo meio dos objetos de luxo expostos nas salas dos pais a fim de granjear fúteis louvores a sua autora (p. 110).

Para Nísia, a educação feminina existente no Brasil visa preparar a mulher para "fazer as delícias de qualquer epicurista em um harém" (p. 61); acredi- 
ta, também, que "nenhuma de nossas brasileiras amará semelhante existência" (p. 61). Retoma o "axioma ridículo de que a fraqueza constitui" um dos primeiros encantos da mulher:

A fraqueza pode excitar e lisonjear o arrogante orgulho do homem [...] mas as carícias de um senhor, de um protetor, não satisfarão uma alma generosa que quer e merece respeito. [...] o homem delicado e justo, compreendendo devidamente este respeito, sabe-o tributar à energia da razão que combate, e não à fraqueza que se humilha (p. 64).

Nísia aguarda uma reforma radical da nossa educação, "quer doméstica, quer pública" (p. 111), a fim de que os jovens se tornem "indivíduos bem morigerados, conspícuos e modestos" (p. 111); tais homens e mulheres serão "capazes de firmar o renome da Nação Brasileira [...] no vasto e fértil campo da civilização moderna" (p. 111). Segundo ela, quando a mocidade se vai "enervando nos vícios", abre "um abismo insondável a si e à pátria" (p. 98). Por esse motivo, Nísia Floresta tem grande apreço pela educação oferecida às inglesas:

Da mesma sorte que a Inglaterra é o modelo da religião, do comércio e da liberdade, as suas mulheres o são das virtudes domésticas e da nobre altivez de seu sexo. [...] A educação da mulher inglesa é, como a liberdade política dos ingleses, fundada na sua moral, e, assim como a verdadeira base de um governo é a liberdade política, conforme observa o ilustre autor do Espirito das Leis, assim também a religião deve ser a base da educação da mulher. O povo inglês compreendeu [...] esta verdade (p. 25).

Em Mulheres e crianças, Cartas a uma noiva e demais obras dirigidas ao público feminino, Maria Amália insere-se no mercado editorial como uma voz feminina, no sentido tradicional do termo: dirige-se às mulheres e aborda assuntos relativos à esfera privada. Nísia, ao contrário, parece indiferente às tradicionais interdições à voz feminina:

[...] as mulheres falam, inicialmente entre elas, na sombra do gineceu ou da casa; mas também no mercado, no lavradouro [...]. A voz das mulheres é [...] uma forma de regulação das sociedades tradicionais onde predomina a oralidade. Mas sua palavra pertence à esfera privada das coisas; ela é da ordem do coletivo e do informal [...] O que é 
recusado às mulheres é a palavra pública [...] O Verbo é apanágio dos que exercem o poder. Ele é o poder [...] Ele faz o homem [...] (Perrot, 2005: 317-318).

A atuação profissional de Nísia Floresta nos campos educacional e cultural mobiliza sujeitos empenhados em desqualificá-la, enquanto ela, indiferente às restrições socialmente impostas à sua condição de mulher, discute política, história e costumes pela imprensa - um debate que pode ter contribuído para preservar/construir uma imagem positiva do Colégio Augusto. Se Maria Amália tenta mostrar às mulheres, em linguagem que considera feminina, aquilo que (em sua opinião) somente os homens perceberam (a emergência da moderna sociedade democrática a diluir tradições, hábitos e preconceitos), Nísia Floresta, menos cuidadosa, considera-se capaz de atuar junto à sociedade brasileira, cujas deficiências (segundo sua análise) saltam aos olhos dos estrangeiros e passam despercebidas aos nacionais. É interessante observar que Nísia recorre às descrições de Saint Hilaire e demais europeus para explicar aos brasileiros a realidade deles e, na ausência de narrativas de viajantes, recorre a cenas observadas por ela em outros países para evidenciar as falhas de nossos costumes e/ou desqualificar algum grupo social (o clero, por exemplo). A autoridade de sua voz não decorre da condição de mulher, mas do contato com a cultura e a sociedade europeias; este cosmopolitismo parece desejado por pais que buscavam uma educação "moderna" para suas filhas.

Postas lado a lado, ambas as obras (cada qual à sua maneira) parecem contribuições para inserir a mulher no universo da cultura letrada, seja pela defesa da educação feminina, seja pela autoria. Pode-se visualizar a importância deste discurso à época quando se retoma descrições de viajantes que, ao percorrer o interior do Brasil, quase sempre eram recebidos pelos donos das casas e poucas vezes encontravam as esposas e filhas. Referindo-se à sociedade brasileira colonial, Jurandir Freire Costa afirma que:

Havia a segregação moura das mulheres e elas nunca aparecendo a ninguém e sempre espreitando pelas frestas das portas e pelas treliças das rótulas, organizavam a intimidade das dependências internas da morada, a subsistência da família, conservando hábitos, transmitindo ensinamentos, mantendo tradições, usos e costumes [...] (Costa, 2004: 81-82).

De fato, a transgressão é tão antiga quanto a norma; não são raros os exemplos (em todos os períodos históricos) de mulheres que zelaram pelo patri- 
mônio da família e/ou cuidaram sozinhas de crianças; a família patriarcal extensa e a nuclear burguesa nem sempre predominaram numericamente, apesar dos esforços da Igreja em sacramentar as uniões. ${ }^{2}$ Ainda assim, Nísia Floresta e Maria Amália Vaz de Carvalho contribuem no movimento de afirmação de um valor positivo à educação letrada feminina, sem o qual as mulheres dificilmente ultrapassariam os limites do "pequeno mundo doméstico" e conseguiriam a participação política.

Notas

1. Deve-se relativizar o sentimento de exclusão de Mme de Staël, considerando as divergências com Napoleão Bonaparte que lhe custaram dissabores e o exílio.

\section{Referências bibliográficas}

ARIÈS, Phillipe. Historia social da criança e da família. Rio de Janeiro: LTC Editora, 1981.

BELLINE, Ana Helena C. Júlia Lopes de Almeida e Maria Amália Vaz de Carvalho: vozes femininas? Dossiê Literatura Feminina. Via Atlântica, $\mathrm{n}^{\circ} .2,1999$.

BRITO, Maria N. C. Gênero e cidadania: referenciais analíticos. Revista Estudos $\mathrm{Fe}$ ministas. vol. 9, $\mathrm{n}^{\circ} .1,2001$.

CARVALHO, Maria Amália Vaz de. $M u$ lheres e creanças (notas sobre educação). Porto: Companhia Portugueza Editora; Rio de Janeiro: Jacintho Ribeiro dos Santos, 1921.
2. No caso do Brasil, uma parcela significativa da população permanecia no celibato ou vivia em concubinato. Predominavam os solteiros entre os brancos pobres e os escravos (Samara, 1983).

\footnotetext{
. Cartas a uma noiva. Porto: Editora Domingos Barreira, s/d.

CHARTIER, Roger. Práticas da leitura. $2^{\mathrm{a}}$ ed. São Paulo: Estação Liberdade, 2001.

Prefácio. In: LACERDA, Lílian de. Álbum de leitura - memórias de vida, histórias de leitoras. São Paulo: Ed. Unesp, 2003.

COSTA, Jurandir Freire. Ordem médica e norma familiar. Rio de Janeiro: Graal, 2004.

D'INCAO, Maria Angela. A mulher e a família burguesa. In: DEL PRIORE, Mary (org.). História das mulheres no Brasil. São Paulo: Contexto, 1997.
} 
DUARTE, Constancia Lima. Posfácio. In: FLORESTA, Nísia. Opúsculo humanitário. São Paulo: Cortez/ Brasília:INEP, 1989.

(org.). Cartas: Nísia Floresta \& Auguste Comte. Santa Cruz do Sul: EDUNISC/ Florianópolis: Editora Mulheres, 2002.

- Nísia Floresta - a primeira feminista do Brasil. Florianópolis: Editora Mulheres, 2005.

ELIAS, N. \& SCOTSON, J. Os estabelecidos e os outsiders - sociologia das relações de poder a partir de uma pequena comunidade. Rio de Janeiro: Jorge Zahar, 2000.

ESTEVES, João. Os primórdios do feminismo em Portugal: a primeira década do século XX. Penélope, $\mathrm{n}^{\mathrm{o}}$.25, 2001, p. 87-102.

FLORESTA, Nísia. Opúsculo humanitário. São Paulo: Cortez/ Brasília: INEP, 1989.

HUNT, Lynn. A invenção dos direitos humanos: uma história. São Paulo: Cia. das Letras, 2009.

KAMITA, Rosana C. Revista "A Mensageira": o alvorecer de uma nova era? Revista Estudos Feministas, vol. 12, Florianópolis, set/dez 2004.

LACERDA, Lílian de. Álbum de leitura memórias de vida, histórias de leitoras. São Paulo: UNESP, 2003.

MAUGUE, Annelise. A nova Eva e o velho Adão: identidades sexuais em crise. In: DUBY, George \& PERROT, Michelle (dir.). História das mulheres no ocidente: o século XIX. Porto: Edições Afrontamento, s/d, p. 581-601.
MORAIS, Maria Arisnete C. Leituras de mulheres no século XIX. Belo Horizonte: Autêntica, 2002.

OUTEIRINHO, Maria de Fátima. Mulheres oitocentistas: George Sand vista por Maria Amália Vaz de Carvalho. In: Estudos em homenagem ao Professor Doutor Antonio Ferreira de Brito. Porto: Universidade do Porto, s/d, p. 299-304 (<http://ler.letras. up.pt/uploads/ficheiros/4394.pdf $>$ ).

PERROT, Michelle. A palavra pública das mulheres. In: As mulheres ou os silêncios $d a$ história. Bauru: EDUSC, 2005.

ROSA, Graziela Rinaldi. Pensando o feminismo de Nísia Floresta. In: Anais: Os feminismos latino-americanos e suas múltiplas temporalidades no século $X X$. (<www.fazendo genero.ufsc.br $>$ )

SAMARA, Eni de Mesquita. A família brasileira. São Paulo: Brasiliense, 1983.

SCHUMAHER, Schuma. Um Rio de mulheres: a participação das fluminenses na história do Estado do Rio de Janeiro. Rio de Janeiro: REDEH, 2003.

STAËL, Germaine de. Das mulheres que cultivam as letras. In: DUBY, George \& PERROT, Michelle (dir.). História das mulheres no ocidente: o século XIX. Porto: Edições Afrontamento, s/d, p. 606-609.

VALADARES, Peggy Sharpe. Prefácio e Introdução. In: FLORESTA, Nísia. Opúsculo humanitário. São Paulo: Cortez/Brasília: INEP, 1989.

\section{Resumo \\ O presente artigo problematiza a estrutura discursiva de duas obras que consideramos vozes femininas na defesa da educação e do trabalho para mulheres com alguma repercussão no Brasil no século XIX: Opúsculo}


humanitário (1853), da brasileira Nísia Floresta (1809 ou 1810-1885) e Mulheres e crianças (1880), da portuguesa Maria Amália Vaz de Carvalho (1847-1921). Procuramos identificar a quem se dirigiam os textos e como justificavam a autoria e a erudição femininas em um momento em que a tradicional interdição da palavra pública e da imprensa às mulheres começava a ser questionada.

Palavras-chave: gênero; cidadania; educação feminina; história da leitura.

\section{Abstract}

The article discusses two books representing women's voices in defense of women's education and work which somehow reverberated in Brazil in the 19th century: Opúsculo humanitário (1853), by the Brazilian writer Nísia Floresta (1809 or 1810-1885), and Mulheres e crianças (1880), by the Portuguese writer Maria Amália Vaz de Carvalho (1847-1921). We tried to identify to whom the texts were written and how they justified women's authorship and scholarship in a time when the traditional prohibition of public speech and of the press to women began to be questioned.

Key words: gender; citizenship; women's education; history of reading.

\section{Résumé}

L'article discute la structure discoursive de deux oeuvres qui représentent des voix féminines en défense de l'éducation et du travail des femmes et qui ont eu quelque répercussion au Brésil au XIXe siècle: Opúsculo humanitário (1853), de la brésilienne Nísia Floresta (1809 ou 1810-1885), et Mulheres e crianças (1880), de la portugaise Maria Amália Vaz de Carvalho (1847-1921). Nous avons essayé d'identifier à qui les textes étaient adressés et comment ils justifiaient le droit d'auteur et l'érudition féminine à un moment où la traditionnelle interdiction du mot public et de la presse aux femmes commençait à être questionnée.

Mots-clés: genre; citoyenneté; éducation féminine; histoire de la lecture. 